average length of stay of patients going from home to residential/ nursing-home care was only 20-30 days. Perhaps the Griffiths Report will alter that too.

St James's University Hospital, Leeds

\title{
Religion and Ageing
}

\section{Mannes Tidmarsh}

Arthur H. Becker, Pastoral theological implications of the ageing process. Religion and Ageing, 2, 3 (1986), 13-30.

Becker begins by remarking on a tendency for some Christian ministers caring for old people to take on the task of counsellor or social worker, thereby avoiding offering 'true pastoral care', by which he means giving attention to 'the spiritual/theological issues involved in the ageing process'. He also identifies a subtle ageism to which some pastors are prone, which leads them to assume that the spiritual/ theological problems of those aged over 65 years are all alike.

The author goes on to argue that pastoral care will be improved if it is realised that the three epochs of ageing give rise to distinct spiritual/theological concerns : for the younger elderly 'What shall I do with my life?'; for the middle-old, 'What about my dying?'; and for the old-old, 'Why must I suffer so?'. He then briefly relates these issues to Jung's polarities and Erikson's 'crisis work' in later life. Becker attributes the life direction/purpose dilemmas of the younger elderly to the entry into retirement, which is interpreted not only as formal retirement from work but also as the enforced withdrawal from responsible social roles, not least roles within the church community. $\mathrm{He}$ cites several studies in support of his contention that concern about death is at its highest among the middle-old group (aged 71-75 years). He emphasises the importance at this stage of life of the virtue of hope, arising both from reflection on the pattern of events in one's past life and from God's promise of a 'new creation'.

The focus of concern for the frail elderly, whom Becker seems to equate with the old-old, is personal pain and a sense of abandonment. He quotes at length Sölles's description of three phases of suffering: mute suffering, anguished outcry of lament, and liberation and change. Pain tends initially to isolate the sufferer and may lead old people in particular to withdraw from supportive relationships in order to avoid becoming a burden. The pastor's role is to reach out and help 
the patient to accept support. The second stage is characterised by the psalmist's cry, 'Out of the depths I have cried to Thee, Oh Lord; Lord hear my voice', and Becker remarks that the pastor's response to this cry may start the process of 'co-determination', which means 'the consideration by both sufferer and compassionate friend of the meaning and function of suffering'. The third phase of the process, liberation and change, emerges from this collaborative work, but only if "whatever meaning is found in the suffering is discovered by the sufferer and not imposed upon her/him'.

Becker ends by relating reminiscence to anamnesis, the remembrance of past experience of God's guidance, suggesting that stimulating anamnesia can be 'one of the main pastoral contributions a minister can make for the ongoing life of the elderly, particularly the frail elderly'.

\section{COM M EN T}

Though this thoughtful paper is addressed principally to those with responsibility for the pastoral care of old people and frames its arguments and examples in terms of Christian theology, it could be of value to anyone working with old people. Its insights into the foci of concern over the period of old age apply equally to those with or without expressed religious belief, and the anxieties identified are likely to surface in encounters other than the strictly 'pastoral'. It would be interesting to see a fuller exploration of Becker's opening comment that ministers often seem to avoid offering 'true pastoral care' by seeking to act as counsellors or social workers. Does this point to a lack of interprofessional understanding/communication, to a perceived inadequacy in the counselling being offered or to a straightforward avoidance of what may be seen as a more personally challenging role?

Christian Council on Ageing, Towcester, Northamptonshire 